\title{
Egzersiz ve Nöroplastisite
}

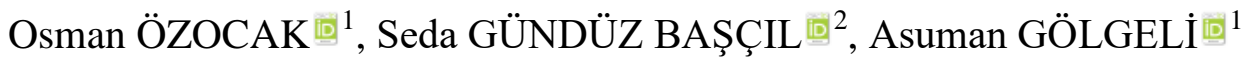

\begin{abstract}
ÖZ
Nöroplastisite, sinir sisteminin yapısını, işlevini ve bağlantılarını yeniden yapılandırarak iç veya dış uyaranlara cevap verme kabiliyetidir. Nöroplastisite, moleküler yapıdan hücresel yapıya, sistemlere, davranışlara kadar pek çok düzeyde tanımlanabilir. Plastisite konusunda yapılan çalışmaların amacı genel olarak beyin hastalıklarını tedavi etmek ve daha güçlü bir hafızaya sahip olabilmektir. Uyarılan bir nöron çevresindeki diğer nöronları uyararak, nöroplastik değişimlere sebep olabilir. Son yıllarda klinik açıdan ağrı, depresyon, şizofreni gibi zihinsel bozukluklar, merkezi sinir sistemi (MSS) yaralanması, inme, Parkinson gibi nörodejeneratif hastalıklar, alkol bağımlılığı, pediatrik / gelişimsel bozukluklar, yaşlanma gibi pek çok faktörün nöroplastisite üzerine etkileri, etki mekanizmaları ve nöroplastisitenin terapötik etkileri üzerine çok sayıda araştırmalar yapılmıştır. Egzersizin nöroplastisite, nörodejeneratif hastalıklar ile zihinsel gelişim, öğrenme ve davranış gibi kognitif fonksiyonlar üzerine olan etkileri hem insanlarda hem de hayvanlarda yapılan birçok çalışmada gösterilmiştir. Bu derlemenin amacı; egzersizin nöroplastisite, nöroplastisite ile ilgili faktörler ve nörodejeneratif hastalıklar üzerine olan etkilerini göstererek, egzersizin nöroplastik değişimle tedaviye yönelik kazanımlarını vurgulamaktır.
\end{abstract}

Anahtar Kelimeler: Nöroplastisite; egzersiz; nörodejeneratif hastalıklar.

\section{ABSTRACT}

\section{Exercise and Neuroplasticity}

Neuroplasticity, the structure, function of the nervous system and reconfigure internal links or external stimuli is the ability to respond. Neuroplasticity, molecular structure to the cellular structure, systems, and behavior can be defined on many levels. The aim of the studies on plasticity is to treat brain diseases in general and to have a stronger memory. When stimulated by stimulating other neurons around a neuron, may lead to changes in neuroplastic. In recent years, such as schizophrenia, depression, pain, clinical aspects of mental disorders, central nervous system (CNS) injury, stroke, Parkinson's, such as neurodegenerative diseases, alcohol abuse, pediatric/developmental disorders, aging and many other factor the effects of neuroplasticity, mechanisms of action and therapeutic effects of numerous studies on neuroplasticity. The effects of exercise on cognitive functions such as neuroplasticity, neurodegenerative diseases via mental development, learning and behavior have been demonstrated in many studies in both humans and animals. The purpose of this review is to demonstrate the effects of exercise on neuroplasticity, neuroplasticity-related factors and neurodegenerative diseases.

Keywords: Neuroplasticity; exercise; neurodegenerative diseases.

\section{Gíiș}

Genel anlamda plastisite kavramı, Yunancada "plaistikos” kelimesinden kaynaklanır. Nöroplastisite kavramı ilk olarak Livingston (1) tarafindan "biçimlendirmek", "şekil vermek" olarak tanımlanmıştır. Eskiden, nöral hücrelerin doğumdan sonra yenilenmediği ve azaldığı görüşü hakimken 1900’lü yıllarda yapılan çalışmalar yerine beyin hücrelerinin kendini ömür boyu onarabileceği, sınırlı olsa da yeni nöron oluşumunun devam ettiği ve bunun beynin farklı bölümlerinde gerçekleştiği kanıtlanmıştır. Nöroplastisite; beyindeki nöronların ve bu nöronların oluşturdukları sinapsların çeşitli çevresel uyaranlara bağlı olarak yapısal özellikleri ve işlevlerindeki değişikliklerdir. Sinir sisteminin bir parçası olan

1 Erciyes Üniversitesi, Tıp Fakültesi, Fizyoloji A.D., Kayseri, Türkiye

2 Bozok Üniversitesi, Sağlık Hizmetleri Meslek Yüksekokulu, Yaşlı Bakımı Bölümü, Yozgat, Türkiye

Sorumlu Yazar / Corresponding Author: Osman ÖZOCAK, e-mail: keremozocak@gmail.com

Geliş Tarihi / Received: 21.07.2018, Kabul Tarihi / Accepted: 04.12.2018 
beyin dokusundaki nöral yolların değişiklikleri, yeniden organize olma yetenekleri ve organizmanın çevreye uyumu için gerekli güç “nöroplastisite” terimi ile ifade edilmiştir (2). Nöroplastisite sayesinde, dendritlerde dallanmanın artması, boylarında uzama, yeni sinaps oluşumu ve var olanların etkinliğinin değişmesi, buna ek olarak yeni nöron oluşumu, hayatta kalımı ve stres altında bozulmaya karşı dirençlerinin artması sağlanabilir (3).

Sinir sisteminde nöronlar, hücreler arası bağlantılar gibi yapıların esnekliği kişinin hayatında önemli fonksiyonlar oluşturur. Beyindeki hücreler arası bağlantı sayısı sabit olmadığından, yeni durumlara ve ihtiyaca göre değişkenlik göstermesi, şekillenebilmesi, mevcut hücreler arası bağlantıların aktivasyonunda değişiklikleri mümkün kılmaktadır (4, Şekil 1).

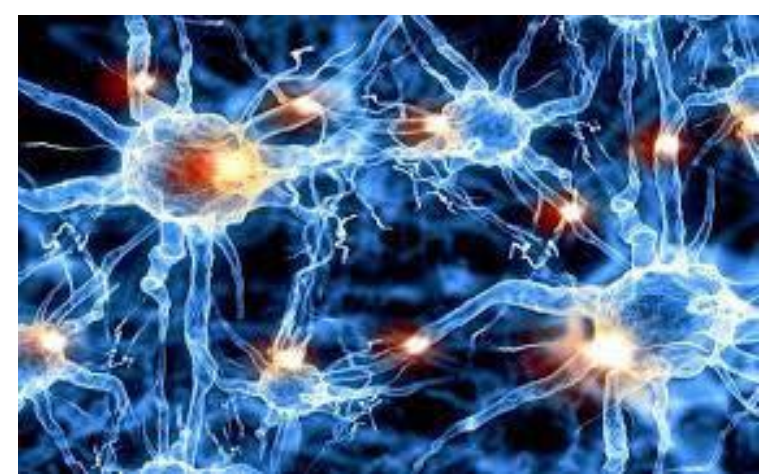

Şekil 1. Beyinde güçlü sinaptik bağlar (4)

Beyin, sinaptik düzeyde değiştirdiği bağlantılarla kendini sürekli olarak yeniden inşa etmektedir. Sinaptik alanların artışı ise çevresel uyaranlardaki artışla kendini gösterir.

Oluşan değişiklikler tek bir nöron ile sınırlı kalmayıp sinaps düzeyine ulaşır ise oluşan adaptif yanıt "sinaptik plastisite" olarak da adlandırılabilir. Sinir sisteminin adaptasyonunda sinaptik etkinliğin değişebilmesi rol oynar. Çevresel değişikliklere uyum ancak öğrenme yolu ile sağlanabilir. Öğrenme de sinaptik plastisite yolu ile gerçekleşir. Şekil 2'de sinaps oluşum hızının yaşla ilgisi gösterilmektedir (5).

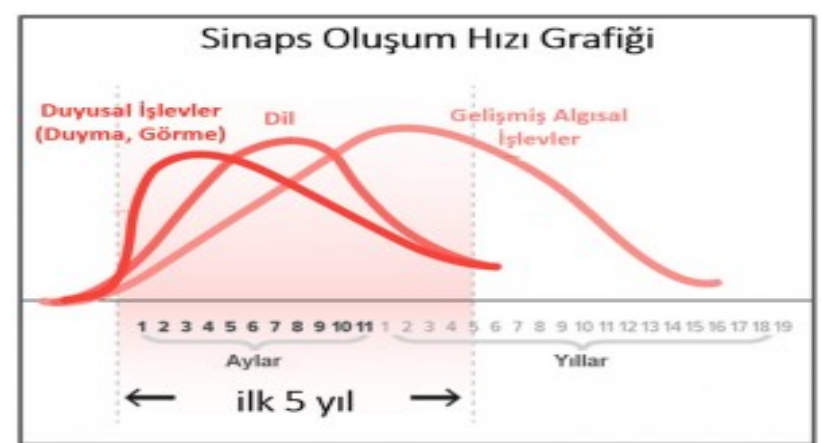

Şekil 2. Sinaps Oluşum Hızı (5)

Çocukluk dönemindeki beyinde gerçekleşen nöroplastisitenin özellikle beynin görme, işitme, motor beceriler ve dil becerileri ile ilgili alanlarında olduğu saptanmıştır. Çocuklarda, müzikle ilgili eğitimlerin özellikle beynin frontoparyetal bölgesindeki nöroplastisitede artışa neden olduğu, beyindeki yapısal değişikliklerin, müzik eğitiminin 15 'inci ayından sonra başladığı belirtilmektedir (6).
Erken çocukluk dönemi nöroplastisite hızının en yüksek olduğu dönemdir. $\mathrm{Bu}$ dönem aynı zamanda belli bir hedefe yönelik çalışmaların daha farklı alanlar açısından önemli sonuçlar verdiği dönemdir. Belirli işlevlerin belirli yaşlarda kazanılmasında bazı kritik dönemlerin (beynin uyaranlara daha fazla duyarlı olduğu dönemler) plastisitenin daha fazla olduğu dönemler olduğu kanıtlanmıştır (7).

Nöroplastisite beynin öğrenme, hatırlama ve unutma yeteneklerine işaret eder. $\mathrm{Bu}$ nedenle yoğun olarak nöroplastisite; hipokampus, amigdala, frontal korteks gibi beyin bölgelerinde görülmektedir. Hipokampustaki subgranüler zon (SGZ) ve subventriküler zon (SVZ) nöral kök hücrelerin oluştuğu en etkin alanlardır. Ayrıca amigdala, frontal korteks ve olfaktör bulbus'da etkin olarak yeni nöronların oluşturulduğu ve plastisite yetilerinin diğer bölgelere göre daha yüksek olduğu bilinmektedir (8).

Fiziksel aktivite, enerji harcamasına yol açan ve iskelet kası tarafından başlatılan vücut hareketidir. Egzersiz; fiziksel uygunluğun bir veya daha fazla bileşeninin korunmasını veya geliştirilmesini amaçlayan, hareket ve artan enerji harcamasına neden olan düzenli, planlanmış ve tekrarlı fiziksel aktivitelerdir (9).

Sedanter ve hareketsiz yaşam, vücudumuzda birçok sağlık problemini de beraberinde getirmektedir. Kronik inaktivite ve hareketsiz yaşamla birlikte nörodejeneratif hastalıklar, kardiyovasküler problemler, kas-iskelet sistemi rahatsızlıkları, obezite, diyabet gibi metabolik bozukluklar, solunum problemleri, yaşlanma, alzheimer, depresyon, şizofreni gibi nöropsikiyatrik rahatsılıklar gibi pek çok rahatsızlığın gelişme riski de önemli oranda artmaktadır. Egzersizin sedanter yaşamın aksine, tüm bu rahatsızlıkların gelişmesini önlediği, risk faktörlerini önemli ölçüde azalttığı ve kognitif fonksiyonları arttırdığı birçok araştırmada gösterilmiştir. Artan fiziksel egzersiz ile birlikte nörogenez, sinaptogenez, anjiyogenez ve nörotrofinlerin salınımı ve nöroendokrinolojik değişikliklerin olduğuna dair kanıtlar elde edilmiştir. Bu çalışmada son yıllarda artan teknolojik gelişmeler, modern tanı ve tedavi metotları 1şığında egzersizin nöroplastisite ve nörodejeneratif hastalıklar üzerindeki etkileri üzerine yapılmış pek çok çalışmayı derleyerek bilim adına bir katkıda bulunmayı amaçladık.

\section{Egzersiz ve Nöroplastisite}

Egzersiz, beyin plastisitesini destekleyen ve sürdüren moleküler ve hücresel basamakları aktive eden, basit ve yaygın olarak uygulanan bir davranıştır (10). Beynin, bir hasar sonrasında kendini iyileştirme yeteneğinin olmadığ miti, yapılan çalışmalar sonrasında yıkılmıştır. Egzersiz sonrasinda artan metabolizma ve gen ekspresyonu ile nörogenez görülür. Bu aşamada beyin plastisitesi devreye girer. Sinir sisteminin en plastik olduğu zamanlar erken dönemler olduğu düşünülmesine rağmen, bu özelliğin yaşam boyu korunduğu belirlenmiştir. Bu sayede değişen koşullara uyum gösterebilme yeteneği sayesinde beyin birçok olumsuz koşuldan en az zararla çıkabilir (11). Hem insan hem de hayvan çalışmalarından alınan sonuçlar, artmış fiziksel egzersizin bazı beyin yapılarının ve hipokampus nöroplastisitesini kolaylaştırdığını ve bunun sonucunda da bilişsel işlevleri (12) ve duygusal (13) ve davranışsal tepkileri (14) desteklediğini ortaya koymaktadır. 
Egzersiz; öğrenme, planlama, bellek, akıl yürütme ve işleme hızı için önemli olan hipokampus gibi temel bilişsel beyin bölgelerinin küçültülmesini yavaşlatmaya veya tersine çevirmeye yardımcı olur $(15,16$, Şekil 3$)$.

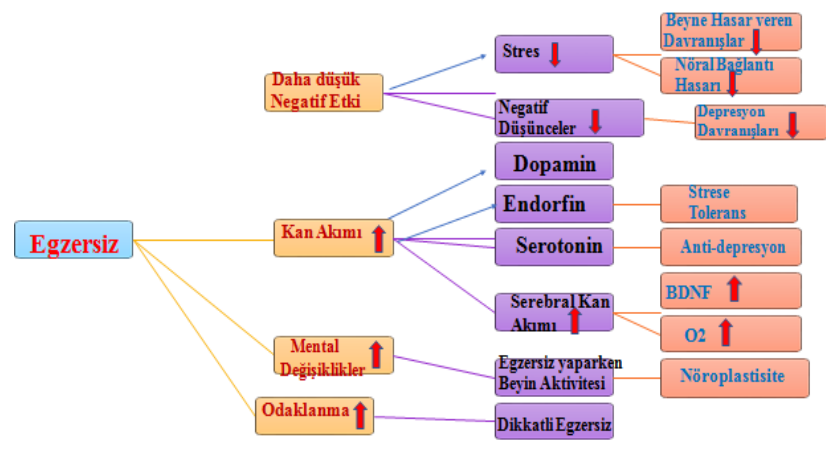

Şekil 3. Fiziksel egzersiz, nöroplastisite ve bilişsel fonksiyon arasındaki ilişkiyi gösteren şema (16)

Budde (12) fiziksel egzersizin nöroplastisiteyi tetikleyebildiği ve bunun da bireyin davranış değişiklikleri ile yeni taleplere cevap verme kapasitesini arttırdığı sonucuna varmıştır. McDonnell ve ark. (17) yaptığ1 çalışmada, 18-60 yaş arası sağlıklı yetişkinlerde üç grupta a- düşük şiddette, 30 dakika, b- orta şiddette, maksimum kalp hızına göre 15 dakika ve c- kontrol grubuna bisiklet egzersizleri yaptırmışlar, egzersizden önce, egzersizden hemen sonra, egzersizden 5 dakika ve 10 dakika sonra serum beyinden türetilen nörotrofik faktör (BDNF) ve kortizol seviyelerini ölçmüşler ve serum BDNF düzeylerinin üç grupta da egzersizden hemen sonra, 5 ve 10 dakika sonra gittikçe artan oranda azaldığını, serum kortizol düzeylerinin ise; düşük şiddette egzersiz yapanlarda egzersizden hemen sonra hizlica arttığını, 5 dakika sonra artmaya devam ederken 10 dakika sonra azaldığını, orta şiddette egzersiz grubu ve kontrol grubunda ise kortizol düzeylerinin egzersizden sonraki dönemlerde BDNF de olduğu gibi azaldığını göstermişlerdir. Düşük şiddette egzersiz yapmanın, orta şiddette egzersiz ve kontrol grubuna göre motor korteksteki nöroplastisiteyi arttırdığını, tek bir aerobik egzersiz programının bile motor kortikal nöroplastisiteyi teşvik ettiğini öne sürmüşlerdir.

Genç erişkinlerde yapılan akut egzersiz çalışmaları, nispeten düşük ila orta şiddetteki aerobik egzersizin tek bir seviyesinin bile transkranyal manyetik stimülasyona cevabı arttırabileceğine dair kanıt sağlamasına rağmen (17), yüksek yoğunluklu aerobik egzersizlerin insan motor korteksindeki transkranyal manyetik stimülasyonun neden olduğu nöroplastisitenin kolaylaştırılmasını engeller ve her zaman indüklenen bir nöroplastisite paradigmasina yanitı geliştiremeyebileceğini göstermektedir (18).

Egzersizin nörogenez üzerindeki etkisini araştıran çalışmalarda, özellikle orta şiddette yapılan aerobik egzersizin nörotrofik faktörleri; BDNF ve insulin-benzeri nörotrofik faktör-1'i (IGF-1) etkileyerek ve antiinflamatuar sitokinlerin salınımını tetikleyerek nörogenezi arttırdığı, öğrenme ve kognitif performansta ilerleme sağladığı birçok çalışmada gösterilmiştir. Yüksek şiddette aerobik egzersizin, organizmada bir stres faktörü gibi görülüp, öğrenmeyi ve plastisiteyi engelleyen santral inflamatuar sitokinlerin salınımına sebep olduğu belirtilmektedir. Egzersizin nörogenezi arttırması için uzun süre devam ettirilmesi ve orta şiddetli aerobik karakterde olması önerilmektedir. Yüksek şiddetli intervalli uygulanan egzersiz programının fiziksel uygunluğu geliştirmesine rağmen nörogenezi arttırmakta başarılı olamadığı randomize hayvan çalışmalarında gösterilmiştir (14).

Hipokampal nörogenez, bilişsel sistem, dikkat ve işlem hız1, öğrenme gibi kognitif fonksiyonlarda anahtar bir rol oynamakta olup, normal koşullar altında lateral ventriküllerin subventriküler zonunda ve dentat girusun subgranular zonunda sürekli olarak gözlenmiştir. Egzersizin hipokampal nörogenez üzerine etkileri aşağıdaki şekilde özetlenmiştir (19, Şekil 4).

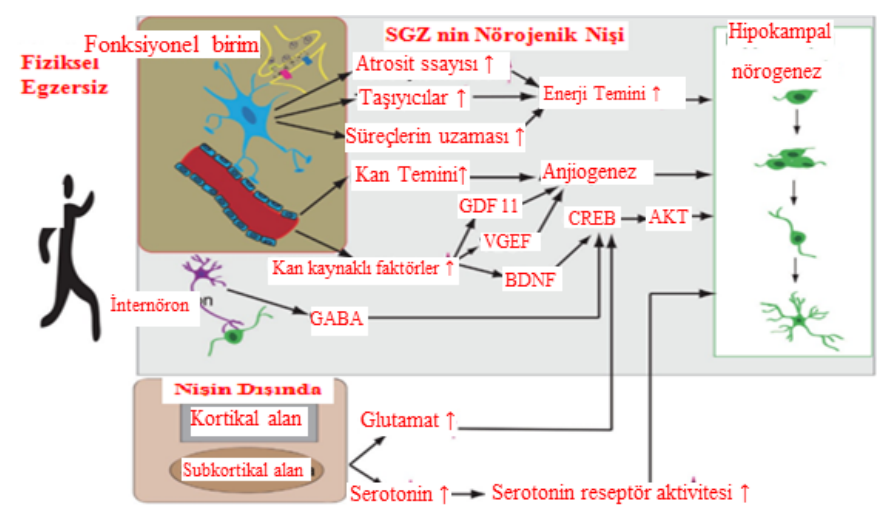

Şekil 4. Egzersizin hipokampal nörogenez üzerine etkileri (19) [Kisaltmalar: GABA (Gama-aminobütirik asit), GDF 11 (büyüme farklılaşma faktörü 11-), SGZ (subragranüler zon), AKT (Protein Kinaz B), CREB (cAMP- yanıt elemanı bağlama protein)]

Petzinger ve ark. (20) yaptıkları çalışmada egzersizin, nörotrofik faktörlerin ekspresyonunun, kan akımının, nörogenezin (özellikle hipokampusta) artışı ile birlikte immün yanıt ve metabolizmanın (gelişmiş mitokondriyal sağlık) değişmesinin nöroplastisiteyi geliştirdiğini göstermişlerdir. $\mathrm{Bu}$ değişiklikler, bazal gangliyonlar ile kortikal ve talamik bağlantıları arasında nöronal devrenin güçlenmesine yol açar. Davranış değişiklikleri ile beraber motor (bilinçli ya da otomatik) beceriler, kognitif fonksiyonlar, zeka ve motivasyon da egzersizle beraber gelişir.

Vilela ve ark. (21)'larının yaptıkları çalışmada 8 hafta boyunca haftada 3-4 gün yaklaşık 50 dakika süresince uygulanan aerobik ve kuvvet antrenmanının yaşlanan sıçanlarda uzamsal bellek ve hipokampal plastik doku üzerine etkilerini araştırmışlardır. Çalışma sonucunda dikkat çekici bir şekilde uzamsal hafızada iyileşme, egzersiz antrenmanından sonra hipokampus içindeki sinaptik plastisite proteinlerinde artış saptanmış daha da ötesi nörotrofik sinyalizasyon (siklik AMP yanıt elemanı bağlama proteini olan CREB ile BDNF ve P75 nörotrofin reseptör) artmıştır.

Mang ve ark. (22) 19-34 yaş aralığında 34 genç sağlıklı yetişkinde yüksek yoğunluklu akut aerobik egzersizin, insan primer motor korteksinde uzun süreli potensiyasyon (LTP) benzeri plastisiteyi kolaylaştırdığını, serebellar devrelerin modülasyonunun motor korteks plastisitesinde egzersize bağlı artışlara katkıda bulunabileceğini, serebellar inhibisyonun egzersizle birlikte azaldığını, 
katelokaminler ve nörotrofik maddelerin egzersizle beraber artmasının motor kortikal plastisiteyi arttırdığını göstermişlerdir.

Dayanıklılık eğitiminin ve egzersizin plazma ve serum BDNF konsantrasyonunu arttırdığına dair pek çok çalışma mevcuttur. Raefsky (23) yaptığı çalışmada 13 genç sağlıklı erkeğe 5 hafta süreyle orta şiddette dayanıklılık antrenmanını yaptırarak BDNF ve insülin dirençlerini ölçmüştür. Egzersiz öncesi, egzersiz sırası ve egzersiz sonrasında BDNF düzeylerinde artma, insülin dirençlerinde azalma tespit etmiştir.

Gomez-Pinilla ve ark. (24) hayvanlar üzerinde yaptıkları bir çalışmada hayvanlara 3-7 gün tekerlekli bisiklet ile egzersiz yaptırdıktan sonra, BDNF ve reseptörü, sinyal transdüksiyon reseptörü (trkB), sinapsin I (mRNA ve fosforile protein), büyüme ilişkili protein-43 (GAP-43), haberci RNA (mRNA) ve siklik AMP yanıt elemanı bağlama proteinin (cAMP-CREB) arttı̆̆ını göstermişlerdir.

Lepley ve ark. (25) yaptıkları çalışmada ön çapraz bağ ameliyatından sonra, 8 haftalı kuadriseps odaklı izokinetik eksantrik egzersiz programını tamamlayan hastaların beyin aktivasyonundaki değişiklikler, nöral eksitabilite ve hasta tarafindan bildirilen sonuçlar incelenmiş sonuç olarak beyin aktivasyonu, kortikospinal ve spinal refleks uyarılabilirliğinde pozitif adaptasyonların kolaylaştırılmasına yardımcı olduğu saptanmıştır. Ayrıca eksentrik egzersizlerin quadriceps kasılmalarını oluşturmak için frontal korteks aktivitesine bağımlılıklarının, ağrı ve semptomlarının azalmasına neden olarak iyileşmenin arttı̆̆ını bildirmişlerdir.

Firth ve ark. (26) aerobik egzersizin havyan modellerinde hipokampal hacmi sürekli olarak arttığını göstermişlerdir. Egzersiz, artan glukokortikoidleri baskılayarak depresyon ve Alzeimer hastalığının gelişme riskini azaltır. Aynı zamanda kardiyovasküler hastalıklar, hipertansiyon, diyabet, dislipidemi, obezite gibi makro düzeydeki risk faktörlerini azaltarak, serebral kan akımını ve glukagon benzeri peptid-1'i (GLP-1) ise arttırarak Alzeimer hastalığının gelişme riskini azaltır (27).

Sedanterlere göre aerobik egzersiz yaptırılan hayvan ve insan gruplarında; hem hipokampal plastisitenin hem de nörokognitif fonksiyonların (dikkat ve işleme hızı, akıl yürütme, hafıza, çalışma belleği, dil becerileri gibi) olumlu gelişmelerle birlikte egzersiz lehine arttığ birçok sistematik derleme ve meta analizde gösterilmiştir. Bununla beraber aerobik egzersizlerin hipokampal plastisiteyi, nörogenezi, beyin kan akımını ve anjiogenezi, beyaz ve gri maddeyi, nörotrofik faktörleri (serum BDNF, IGF-1), sinaptik plastisiteyi (LTP potensiasyonu) arttırdığını göstermişlerdir. Aynı zamanda aerobik egzersizlerin demans, şizofreni, Alzheimer gibi özellikleri de olan nöropsikiyatrik hastalıkların ve Parkinson, inme gibi nörodejeneratif hastalıkların gelişme riskini azalttığı ve önlediği de bildirilmektedir (28).

Perini ve ark. (29) yaşları ortalama 23 olan 38 genç sağlıklı yetişkinlere, tek bir seanslık orta şiddette bisiklet ergometresinde aerobik egzersiz programı uygulamışlardır. Aerobik egzersizlerin korteksin görsel ve motor bölgelerinde öğrenme yeteneklerini geliştirebildiğini, egzersiz bittikten sonra 30 dakika boyunca bu olumlu etkilerin devam ettiğini bildirmişlerdir. Görsel ve motor öğrenmenin nöral plastisite ile sinaptik aktivitenin bir göstergesi olduğunu ve egzersizle beraber nöroplastisitenin de geliştiği sonucuna varmışlardır.

Hayes ve ark. (30) yaşlanmaya bağlı olarak beyindeki kardiorespiratuar zindelik ile ilişkili nöroplastisitenin zayıfladığını vurgulamışlardır. Hafif şiddette aerobik egzersizlerin kardiyorespiratuar enduransı arttırması nedeniyle nöroplastisiteyi, nörogenezi, anjiogenezi geliştirdiğini ve nörotrofik faktörleri arttırdığını göstermişlerdir. Aynı zamanda egzersizin yaşlanmayla birlikte oluşan kardiyorespiratuar, kas iskelet sistemi, nöropsikiyatrik ve nörodejeneratif hastalıkların gelişme riskini azalttığı sonucuna varmışlardır.

Cottman ve ark. (10) yaşla ilişkili bilişsel gerilemeyi desteklemek için; inflamasyon, nörovasküler değişiklikler ve MSS yapısı ve fonksiyonundaki değişiklikler olmak üzere üç önemli faktörü vurgulamışlardır. Egzersizin ise; bu üç faktörü etkileyerek faydalı olduğunu, nörogenezi desteklediği, serebral kan akımı ve anjiogenezi arttırdığını ve daha iyi bilişsel performansa neden olduğunu göstermişlerdir. Egzersiz, santral sinir sisteminde mikrogliaların, monosit ve komplement aktivasyonunun azalmasiyla sistemik iflamasyonu etkiler. Egzersizin yaşla ilişkili perisit kaybını, temel zar bileşenlerini ve nörovasküler birimdeki astrosit reaktivitesini ve miyeloid hücrelerdeki kompleman indüksiyon miktarını azalttığını tespit etmişlerdir. Egzersiz; perisit ve aquaporin 4 (AQP4) ve bazal membran bütünlüğü kayıplarının ve fibrin kaçağının azalması ile anjiogenezi etkiler. Nörogenezi ise; hipokampal volümün artması, sinaptik proteinlerin kaybı azalması ve nöroplastisitede artış sağlar.

Rehveld ve ark. (31) yaşlı bireyler için özel olarak tasarlanmış 6 aylık dans programının çalışma belleği ve dikkat gibi daha yüksek bilişsel süreçlerle ilişkili olan ve yaşa bağlı düşüşten etkilenen özellikle singulat korteks, insula, korpus kallosum ve duyu-motor korteks gibi beyin bölgelerinde hacimleri artırdığını, plazma BDNF düzeylerinde artışlar gösterilmiştir.

Rogge ve ark. (32) 12 haftalık denge eğitiminin görsel, işitsel, hareketi planlama ve mekânsal bilgini farklı duyusal entegrasyonlarının yer aldığı bölgeler olan beynin üst temporal korteksi, görselle ilgili korteksi, arka singulat korteksi ve üst frontal yarığında nöroplastisiteyi indüklediği, bellek ve mekansal biliş gibi bilişsel işlevleri geliştirdiğini, premotor, frontal ve paryetal kortekslerde gri cevher ve hacim artışının ise denge performansında ve kortikal kalınlıkta artışa neden olduğunu tespit etmişlerdir.

Lucas ve ark. (33) yüksek yoğunluklu aralıklı egzersiz eğitiminin serebrovasküler sağlık üzerine yaptıkları çalışmada, egzersiz eğitiminin beyin yapısını ve işlevini değiştirebileceği ve sistemik fonksiyondaki değişiklikler yoluyla beyinle ilgili işlev bozukluğu ve hastalık riskini azaltan mekanizmaları özetlemişlerdir (Şekil 5).

Mischel ve ark. (34) 'Beyin sapı sempatik kontrolünde aktivite ile ilişkili nöroplastisite' adlı çalışmasında; sempatik aktivitenin bazal ve refleks kontrolü için kritik bir beyin bölgesi olan rostral ventrolateral medulladaki (RVLM) değişiklikleri sıçanlarda araştırmışlardır. Periferik ve merkezi afferentler de dahil olmak üzere egzersizle ilgili girdinin entegrasyonunda RVLM anahtar bir beyin bölgesi olarak görev yapmaktadır. 


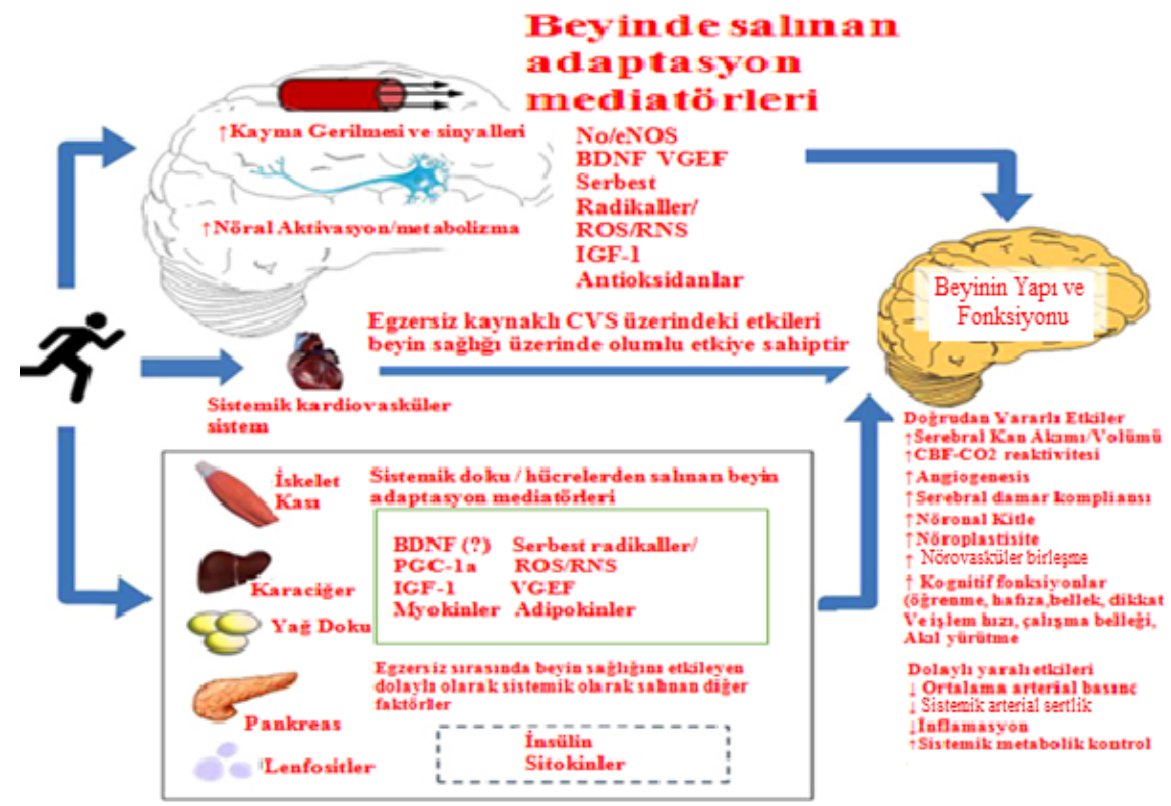

Şekil 5. Egzersiz eğitiminin beyinle ilgili işlev bozukluğu ve hastalığın riskini azalttığı önerilen mekanizmaları özetleyen şema (33) [Kısaltmalar: SKA: Serebral Kan Akımı, eNOS (Endotelyal nitrik oksit sentaz), IGF-1 (İnsülin benzeri büyüme faktötü-1), NO (Nitrik oksit), PGC-1 $\alpha$ (Peroksizom proliferatör aktive reseptör- $\gamma$ koaktivatör) ROS (Reaktif oksijen türleri), RNS (Reaktif nitrojen türleri)]

RVLM, omuriliğin intermediolateral hücre kolonundaki sempatik pregangliyonik nöronları innerve eden bulbospinal nöronlar yoluyla bazal ve refleks sempatik aktivitenin kontrolü için en önemli beyin bölgelerinden biridir. RVLM nöronlarının aktivitesi, glutamat (eksitatör nörotransmitter) ve gama aminobütirik asit (GABAinhibitör nörotransmitter) tarafindan düzenlenir.

Kronik inaktivasyonun yapısal, moleküler ve hücresel nöroplastisitenin RVLM'de glutamaterjik sinir iletimini arttırması ile sempatik sinir sistemi aktivasyonun (SSSA) artmasına ve GABA'nın inhibisyon etkisinin azalmasına neden olur. Kronik inaktivasyona bağlı olarak dentritik sinaps dallanmaları ve aktivite ile ilişkili gen ekspresyonu da önemli ölçüde azalırken, düzenli uzun süreli egzersizin tüm bu etkileri tersine çevirdiği bilinmektedir. Sedanter yaşamın ya da kronik inaktivitenin kardiyovasküler (KVS) hastalık riskini ve kan basıncını ve SSSA'yı arttırırken, uzun süreli egzersizin ise tam tersine kan basıncı, KVS hastalık riskini ve SSSA'yı azalttığını göstermişlerdir. Aynı zamanda RVLM de kronik egzersizin moleküler, yapısal ve hücresel nöroplastisite üzerine pozitif etkilerini de göstermişlerdir. Arteriyel barorefleks, karotis kemorefleksi ve kas mekaniği ve metaborefleks gibi bu afferent impulslar sedanterik yaşamda işlevsizdir ve disfonksiyon egzersiz antrenmanı ile iyileștirilebilir veya düzeltilebilir $(33,34)$.

Yapılan bașka bir çalıșmada ise Inoue ve ark. (35) farelerde koşu bandında uzun süreli egzersizlerin GABAerjik sinapsların motor kontrol üzerindeki düşük seviyeli inhibisyonunun, nöroplastisite, ve nörogenezde önemli rol oynayan serebellar BDNF ile mRNA'nın ekspresyonunu arttırdığını, motor kortekste BDNF protein düzeyini artırdığını, aerobik egzersizden denge koordinasyona motor öğrenmenin transferini kolaylaştırdığını ve artmış nöral aktivitenin öğrenme ve belleği geliştirdiğini ortaya koymuşlardır.

Seidel ve ark. (36), karmaşık denge görevlerinin ilgili nöroplastisitede motor öğrenme ile olan ilişkisini dayanıkl11ık sporcuları ile antrene olmayan sporcular arasında karşılaş̧ırmışlar ve dayanıklılık sporcularında statik denge performansının daha fazla olduğunu ve dayanıklılık egzersizinin motorla ilişkili beyin bölgelerinde nöroplastik mekanizmalara yol açabileceğini göstermişlerdir.

Ballesteros ve ark. (37), birçok özgün araştırma makalesi, klinik araștırmaları, derlemeleri, hipotez ve teorilerinden derledikleri makalesinde; egzersizin, bilişsel eğitimin, öğrenme terapisinin, bilgisayar ve video oyunlarının yaşlanmayla birlikte azalan kognitif fonksiyonlar ve beyin plastisitesinin arttığını ve bilişsel gerilemeyi önlediğini göstermişlerdir.

\section{Egzersiz, Nörodejeneratif Hastalıklar ve Nöroplastisite}

Dunlop (38), medulla spinalis hasarından (SCI) sonra egzersizin hücresel ve moleküler aktiviteye bağımlı MSS plastisitesi üzerine etkisini hem hayvanlarda (sıçanlarda) hem de insanlarda yapılan çalıșmaları sistematik derleme yaparak incelemiştir

Egzersiz, Alzheimer ve Parkinson gibi yaşla ilgili nörodejeneratif hastalıklarda ve bilişsel gerilemede azalmayı önlemektedir. Hipkampal nörogenezin kuvvetli bir arttırıcısı olan fiziksel egzersiz, bilişsel gerilemeler için potansiyel bir terapi olarak ortaya çıkmıştır (19).

Hayvan ve insan çalışmalarında son yirmi yılda yapılan araștırmalar inme sonrası yapılan aerobik egzersizlerin BDNF salınımı ve nöroplastisite üzerine olumlu etkisinin olduğunu, beyindeki hasarın iyileşmesi ve rehabilitasyon süreçlerini kolaylaştırdığını, akut, alt akut ve kronik fazlar gibi inme sonrası iyileșmenin farklı fazlarını karşılaştıran egzersize sistemik BDNF cevapları konusunda daha fazla kanıt gerekli olduğu sonucuna varılmıstır (39).

Austin ve ark. (40) inme sonrası bir dizi hayvan modelini kullanarak yaptıkları çalışmada aerobik egzersizin (AE) beyin onarım parametreleri (lezyon hacmi, oksidatif hasar, inme ve hücre ölümü, nörogenez, anjiogenez ve 
stres belirteçleri) üzerindeki etkileri araştırmışlardır. İnme sonrası yapılan aerobik egzersizin, oksidatif hasar, inme ve hücre ölümünü azalttığı, inmenin etkilerini tersine çevirdiği, nöroplastisiteyi arttırarak fonksiyonel kapasiteyi iyileştirdiği, nörogenezi ve anjiogenezi geliştirdiği sonucuna ulaşmışlardır. Aynı zamanda inme sonrası 24 saatte yaptırılan orta düzeydeki kuvvet egzersizlerinin (10 m/dakika, haftada 5-7 gün yaklaşık 30 dakika) 4 haftada belirgin fayda sağladığını, lezyon hacmini ve korunan perilezyonlu dokuyu oksidatif hasara ve ateşlenmeye karşı azalttığını göstermişlerdir.

İnmeden sonra yapılan aerobik egzersizin beyindeki olumlu etkileri için dolaylı ve doğrudan etkileri gösterilmiş, dolaylı etkileri, beyin sağlığını etkileyen çevresel risk faktörlerinin azaltılmasına neden olduğu bildirilmiştir. Kardiyorespiratuar ve kas-iskelet sisteminin fiziksel zindeliğinin artması, sistemik ve santral sinir sistemi (SSS) inflamasyonunun azalması, serebral kan akımının artması aerobik egzersizin dolaylı etkileridir. Direkt etkileri ise, nörotrofik faktörlerin (BDNF, nörotrofin-3), dopamin ve serotonin gibi nörotransmitterlerin artışı sonucu nöroplastisiteyi, nörogenezi, nöroproteksiyonu arttırır. Sonuç olarak hem direkt hem de dolaylı etkileri kognitif fonksiyonları (öğrenme, hafıza, dikkat gibi), uyanıklığı arttırırken, nörodejenerasyonu da azaltarak beyin sağlı̆̆ını geliştirir. İnme sonrası aerobik egzersizin; BDNF artışı ile birlikte hipokampus, serebellum ve spinal kordda nöroplastisiteyi geliştirdiği, motor beceri, dikkat, işlev hızı ve öğrenmeyi nöronal devrelerde desteklediği, uzun süreli potensiasyon ve dentrit oluşumunu arttırdığ 1 gösterilmiştir.

Crozier ve ark. (41) inaktivite, kondüsyonsuzluk ve artan kardiyovasküler olay riskine neden olan inme sonrası yapılan yüksek yoğunluklu kardiyovasküler egzersizlerin ve hatta tek bir kardiyovasküler egzersizin bile nöroplastik mekanizmayı harekete geçirerek nöroplastisiteyi, hipokampal nörogenezi geliştirdiğini, BDNF, IGF-1 gibi nörotrofik faktörler ile vazoaktif/büyüme faktörlerindeki artışın inme sonrası motor öğrenme ve motor becerilerinin korunmasını sağladığını ve iyileştirdiğini belirtmişılerdir.

Egzersizin Parkinson ve nöroplastisiteye olan etkileri üzerine yapılan bir çalışmada, sedanter yaşamla birlikte Parkinson hastalığının motor semptomlarının (yürüyüş bozukluğu, postural instabilite, düşme gibi), motor olmayan semptomlarının (depresyon, apati, kognitif azalma, konstipasyon, uyku problemleri, yorgunluk), sekonder problemlerin (osteoporoz, kardiyovasküler hastalıklar, ağrı gibi) artışı ile birlikte mortalitenin arttığı gösterilmiş, buna karşılık düzenli bir egzersiz programının tüm bu semptomların azalmasına, nöroplastisiteyi geliştirmesine neden olduğu tespit edilmiştir (42).

Petzinger ve ark. (20)'nın çalışmasında Parkinsonlu hastalarda görülen dopamin eksikliğinin egzersizle beraber düzeldiği ve arttığı, egzersizin hem nöroresterasyona hem de nöroproteksiyona neden olduğu gösterilmiştir. Egzersizin nöroproteksiyon etkisinin sonucu olarak BDNF, dopamin, tirozin hidroksilaz artarken, dopamin taşıyıcıları azalmıştır. Egzersizin nöroresterasyon etkisinin sonucu olarak ise dopamin salınımı, glutamat reseptör geçişi, hipokampal nörogenez, kan akımı (striatum, prefrontal korteks, substantia nigra, serebellum da), BDNF, leptin, mikroglia, IGF-1, sitokinler artarken, dopamin taşıyıcıları azalır ve striatumdaki dopamin konsantrasyonu değişmez. Parkinson hastalarında aerobik egzersizle birlikte, motor becerilerin geliştiği, sinapslarda nörotransmitterlerin reseptörlerin ve dentritik dallanmaların arttığı, nörotrofik faktörlerin, kan akımının, immün sistemin, nörogenezin, anjiogenezin ve metabolizmanın artarak beyin sağlığını geliştirdiği, bilinçli ve otomatik motor hareketlerin geliştiği, kognitif fonksiyonların (yürütme fonksiyonu, zeka ve motivasyon gibi) geliştiği vurgulanmıştır.

Aerobik egzersiz, bazal ganglionlar, serebellum, korteks, talamus ve beyin sap1 kontrol devresindeki beyin devrelerini geliștirir. Aerobik egzersizlerin sinaptogenezin değiştirilmesinde, dopamin ve glutamat nörotransmisyonunun modüle edilmesinde, azalmış oksidatif stres ve nöroinflamasyon üzerine etkileri vardır. Parkinson hastalarında egzersiz, motor kontrol ile birlikte antioksidan aktivitenin artışıyla kişinin performansı ve yaşam kalitesinin gelişmesine neden olur $(43,44)$.

da Silva ve ark. (45) Parkinson hastalarında egzersiz ile nörotrofik faktörlerin düzenlendiğini göstermişlerdir. Gönüllü egzersizle ve tredmil egzersizleri gibi zorlayıcı egzersizlerle kronik stresin ve oksidatif stresin azaldığını, asetilkolin sentezinin, nörotrofik faktörlerin arttığını vurgulamışlardır.

Egzersizle beraber BDNF, IGF-1, glial kaynaklı nörotrofik faktör (GDNF) ve vasküler endothelial büyüme faktörü (VEGF) gibi nörotrofik faktörlerin salınımının artması, sinaptik aktivasyonunun düzenlenmesiyle birlikte nörotransmitter salınımın artışına ve taşıyıcı proteinlerin ve veziküllerin düzenlenmesine neden olur. Aynı zamanda egzersiz nöroproteksiyona, apoptozisin baskılanmasına neden olarak anjiogenezi arttırır $(45,46)$.

Mak ve ark. (47) Parkinsonlu hastalarda en az 12 haftalık süren fiziksel tedavi ve egzersiz eğitimleri (kas kuvvetlendirme egzersizleri, denge-koordinasyon egzersizleri, yürüme egzersizleri, aerobik egzersizler, progressif dirençli egzersizler, dans, tai chai gibi) ile uzun süreli düzelme, beyin ile ilgili nöral ağların modifikasyonu yoluyla yeni davranışların öğrenildiğini, motor ve bilişle ilişkili devrelerde nöroplastisitenin varlığını gösterdiğini, antienflamatuar sitokinlerin ekspresyonunun yükseldiğini, proinflamatuar sitokinlerin ve aktive edilmiş mikroglia düzeylerinin azaldığını ve mitokondriayal fonksiyon bozukluklarının azaldığını, nörotoksinlere karşı antioksidan savunmanın arttığını bulmuşlardır.

Sandroff ve ark. (48) yaptıkları çalışmada; başlangıçta inflamatuar süreçler, MSS'nde aksonların demiyelinizasyonu ile birlikte yaygın bozulmuş hareketlilik ve kognisyonun (biliş) görüldüğü Multipl Sklerozlu (MS) hastalarda egzersizin adaptif merkezi sinir sistemini nöroplastisitesini harekete geçirdiğini, nörorehabilitasyon için bütüncül, sistem çapında bir uyaran olduğunu göstermişlerdir. Egzersiz davranışı, hareketlilik ve biliş sırasında fizyolojik sistemlerin düzenlenmesi için gerekli olan nöral ağlardaki çoklu duyu girdi ve karmaşık motor çıktının bütünleştirici işlemine dayanan aktiviteye bağlı nöroplastisite ile ortaya çıkan uyarlamaları tanımlayan yeni bir kavramsal çerçeve önermişler ve bu çerçevenin de genel popülasyonda ve 
MS'li hastalarda hareketlilik ve kognisyondaki gelişmeleri açıklayan beynin kortikal/subkortikal bağlantıları, yapısı ve moleküler/hücresel mekanizmaları (BDNF artışı, nörogenez, anjiogenez gibi faktörler) üzerine egzersizin etkilerinin sistematik incelenmesi için bir aşama oluşturduğunu savunmuşlardır. Akut ve kronik egzersizin etkilerinin, beyinde özellikle hipokampal ve prefrontal kortikal bölgelerde, talamusta yaygın olarak görüldüğünü tespit etmişlerdir.

Liu ve ark. (49) yaptıkları çalışmada 7 hafta boyunca kronik hafif stres protokolü uygulanan sıçanlara 4 hafta süresince yüzme programı uygulamışlardır. Sonuç olarak oluşan depresyon benzeri davranışların yüzme ile tersine çevrildiği ve yüzme egzersizin bu etkisinin hipokampal plastitisite ile ilişkisi olan ve büyüme ile bağlantılı olan protein ekspresyonları, büyümeye ilişkin protein-43 (GAP-43) ve sinaptofizin (SYN) vasitasıyla olduğunu belirtilmişlerdir.

\section{SONUÇ}

Güncel bilgiler 1şı̆̆ında egzersizin nöroplastisiteyi geliştirdiği, nörogenez, anjiogenez, LTP potensiyasyonunu arttırarak bilişsel, duyusal ve davranışsal fonksiyonları iyileştirdiği sonucuna varılmıştır. Aynı zamanda gelişen nöroplastisite ile birlikte nörodejeneratif, nöropsikiyatrik, kardyovasküler rahatsızlıkların, sedanter yaşamın getirdiği diğer komplikasyonların önlenmesi ve azaltılmasında, ayrıca yaşlanmanın geciktirilmesinde egzersizin tartışmasız önemli yeri olduğu vurgulanmıştır.

\section{KAYNAKLAR}

1. Livingston RB. Brain Mechanisms in Conditioning and Learning. Neurosciences Research Program Bulletin. 1996; 4(3): 349-54.

2. Apak S. Gelişim Nörolojisi. 2. Baskı. İstanbul: İstanbul Üniversitesi Yayınlar1; 2001.

3. Uzbay T. Anksiyete ve Depresyonun Nörobiyolojisi. Klinik Psikiyatri Dergisi. 2004; 4(3): 1-11.

4. Turhan B, Özbay Y. Erken Çocukluk Eğitimi ve Nöroplastisite. Uluslararası Erken Çocukluk Eğitimi Çalışmaları Dergisi. 2016; 1(2): 58-68.

5. Nelson CA. The Neurobiological Bases of Early Intervention. In: Shonkoff JP, Meisels SJ, editors. Handbook of Early Childhood Intervention. Second edition. Cambridge, MA: Cambridge University Press; 2000. p. 204-27.

6. Hyde KL, Lerch J, Norton A, Forgeard M, Winner E, Evans AC. The Effects of Musical Training on Structural Brain Development. Annals of the New York Academy of Sciences. 2009; 1169(1): 182-6.

7. Hensch TK. The Power of the Infant Brain. Scientific American. 2016; 314(2): 64-9.

8. Ma DK, Bonaguidi MA, Ming GL, Song H. Adult Neural Stem Cells in the Mammalian Central Nervous System. Cell Research. 2009; 19(6): 672-82.

9. Budde H, Schwarzc R, Velasques B, Ribeiro P, Holzweg M. Machado S, et al. The Need for Differentiating Between Exercise, Physical Activity, and Training. Autoimmunity Reviews. 2016; 15(1): 110-1.
10. Cotman CW, Berchtold NC. Exercise: A Behavioral Intervention to Enhance Brain Health and Plasticity. Trends in Neurosciences. 2002; 25(6): 295-301.

11. John GR, Laitman BM. Understanding How Exercise Promotes Cognitive Integrity in the Aging Brain Plos Biology. 2015; 13(11): 1-6.

12. Yau SY, Li A, Sun X, Fontaine CJ, Christie BR, So K-F. Potential Biomarkers for Physical Exercise Induced Brain Health. In: Wang M, editor. Role of Biomarkers in Medicine. UK, London: IntechOpen; 2016. p. 169-91.

13. Kolb B, Gibb R, Robinson TE. Brain plasticity and Behavior. American Psychological Society. 2003; 12(1): $1-5$

14. Budde H, Wegner M, Soya H, Voelcker- Rehage C, McMorris T. Neuroscience of Exercise: Neuroplasticity and Its Behavioral Consequences. Neural Plast. 2016; 2016: 3643879.

15. Hotting K, Roder B. Beneficial Effects of Physical Exercise on Neuroplasticity and Cognition. Neuroscience and Biobehavioral Reviews. 2013; 37(9): 2243-57.

16. Kelly MP. Train your Brain-Holistic Benefits of Exercise on the Brain. 15th The Society of Chinese Scholars on Exercise Physiology and Fitness (SCSEPF) Annual Conference; Hong Kong Baptist University; 2016 July 22-26; China.

17. McDonnell MN, Buckley JD, Opie GM, Ridding MC, Semmler JG. A Single Bout of Aerobic Exercise Promotes Motor Cortical Neuroplasticity. Journal of Applied Physiology. 2013; 114(9): 1174-82.

18. Smith AE, Goldsworthy MR, Wood FM, Olds TS, Garside T, Ridding MC. High-intensity Aerobic Exercise Blocks the Facilitation of iTBS-induced Plasticity in the Human Motor Cortex. Neuroscience. 2018; 373: 1-6.

19. Ma Chun-Lian, Ma XT, Wang JJ, Liue H, Chend Y-F, Yang Y. Physical Exercise Induces Hippocampal Neurogenesis and Prevents Cognitive Decline. Behavioural Brain Research. 2017; 317(2017): 332-9.

20. Petzinger GM, Fisher BE, Sarah M, Beeler JA, Walsh JP, Jakowec MW. Exercise-Enhanced Neuroplasticity Targeting Motor and Cognitive Circuitry in Parkinson's Disease. Lancet Neurology. 2013; 12(7): 716-26.

21. Vilela TC, Muller AP, Damiani AP, Macan TP, da Silva S, Canteiro PB, et al. Strength and Aerobic Exercises Improve Spatial Memory in Aging Rats Through Stimulating Distinct Neuroplasticity Mechanisms. Molecular Neurobiology. 2017; 54(10): 7928-37.

22. Mang CS, Brown KE, Neva JL, Snow NJ, Campbell KL, Boyd LA. Promoting Motor Cortical Plasticity with Acute Aerobic Exercise: A Role for Cerebellar Circuits. Neural Plasticity. 2016; 2016: Article ID: 6797928. doi:10.1155/2016/6797928.

23. Raefsky SM, Mattson MP. Adaptive Responses of Neuronal Mitochondria to Bioenergetic Challenges. Roles in Neuroplasticity and Disease Resistance. Free Radical Biology and Medicine. 2017; 102: 203-16.

24. Gomez-Pinilla F, Ying Z, Roy RR, Molteni R, Edgerton VR. Voluntary exercise induces a BDNF- 
mediated mechanism that promotes neuroplasticity. Journal of Neurophysiology. 2002; 88(5): 2187-95.

25. Lepley LK, Grooms DR, Burland JP, Davi SM, Mosher JL, Cormier ML, et al. Eccentric CrossExercise after Anterior Cruciate Ligament Reconstruction: Novel Case Series to Enhance Neuroplasticity. Physical Therapy in Sport. 2018; 34: 55-65.

26. Firth J, Stubbs B, Vancampfort D, Schuch F, Lagopoulos J, Rosenbaum S, et al. Effect of Aerobic Exercise on Hippocampal Volume in Humans: A Systematic Review and Meta-analysis. Neuroimage. 2018; 166: 230-8.

27. Gürpınar D, Erol A, Mete L. Depresyon ve Nöroplastisite. Klinik Psikofarmakoloji Bülteni. 2007; 17(2): 100-10.

28. Smith PJ, Blumenthal JA, Hoffman BM, Cooper H, Strauman TA. Bohmer WK, et al. Aerobic Exercise and Neurocognitive Performance: A Meta- Analytic Review of Randomized Controlled Trials. Psychosomatic Medicine. 2010; 72(3): 239-52.

29. Kandola A, Hendrikse J, Lucassen PJ, Yücel M. Aerobic Exercise as a Tool to Improve Hippocampal Plasticity and Function in Humans: Practical Implications for Mental Health Treatment. Frontiers in Human Neuroscience. 2016; 10(373): 1-25.

30. Perini R, Marta B, Michela C, Anna F, Carlo AM. Acute Effects of Aerobic Exercise Promote Learning. Scientific Reports. 2016; 6(25440): 1-8.

31. Rehfeld K, Lueders A, Hökelmann A, Lessmann V, Kaufmann J, Brigadski T, et al. Dance Training is Superior to Repetitive Physical Exercise in Inducing Brain Plasticity in the Elderly. Plos One. 2018; 13(7): $1-15$.

32. Rogge AK, Röder B, Zech A, Hotting K. ExerciseInduced Neuroplasticity: Balance Training Increases Cortical Thickness in Visual and Vestibular Cortical Regions. Neuroimage. 2018; 179: 471-9.

33. Lucas SJE, Cotter JD, Brassard P, Bailey DM. Highintensity Interval Exercise and Cerebrovascular Health: Curiosity, Cause, and Consequence. Journal of Blood Flow-Metabolism. 2015; 35(6): 902-11.

34. Mischel NA, Subramanian M, Dombrowski MD, Llewellyn-Smith IJ, Mueller PJ. (In)activity-related Neuroplasticity in Brainstem Control of Sympathetic Outflow: Unraveling Underlying Molecular, Cellular, and Anatomical Mechanisms. American Journal of Physiology. Heart and Circulatory Physiology. 2015; 309(2): 235-43.

35. Inoue T, Ninuma S, Hayashi M, Okuda A, Asaka T, Maejima H. Effects of Long-term Exercise and Lowlevel Inhibition of GABAergic Synapses on Motor Control and the Expression of BDNF in the Motor Related Cortex. Neurological Research. 2018; 40(1): 18-25

36. Seidel O, Carius D, Kenville R, Ragert P. Motor learning in a complex balance task and associated neuroplasticity: A comparison between endurance athletes and nonathletes. Journal of Neurophysiology. 2017; 118(3): 1849-60.

37. Ballesteros S, Rehage CV, Bherer L. Editorial: Cognitive and Brain Plasticity Induced by Physical Exercise, Cognitive Training, Video Games, and
Combined Interventions. Frontiers in Human Neuroscience. 2018; 12: 1-7. Article ID: 169. doi: 10.3389/fnhum.2018.00169.

38. Dunlop SA. Activity-dependent Plasticity: Implications for Recovery after Spinal Cord Injury. Trends in Neurosciences. 2008; 31(8): 410-8.

39. Alcantara CC, García-Salazar LF, Santos GL, Reisman DS, Russo TL. Post-stroke BDNF Concentration Changes Following Physical Exercise: A systematic review. Frontiers in Neurology. 2018; 9: 1-12. Article ID: 637. doi: 10.3389/fneur.2018.00637.

40. Austin MW, Ploughmana M, Glynnb L, Corbett D. Aerobic Exercise Effects on Neuroprotection and Brain Repair Following Stroke: A systematic review and perspective. Neuroscience Research. 2014; 87: 815.

41. Crozier J, Roig M, Eng JJ, MacKay-Lyons M, Fung J, Ploughman M, et al. High-Intensity Interval Training After Stroke: An Opportunity to Promote Functional Recovery, Cardiovascular Health, and Neuroplasticity. Neurorehabilitation and Neural Repair. 2018; 32(6-7): 543-56.

42. Pin-Barre C, Laurin J. Review Article Physical Exercise as a Diagnostic, Rehabilitation, and Preventive Tool: Influence on Neuroplasticity and Motor Recovery after Stroke. Neural Plasticity. 2015; 2015:1-12. Article ID: 608581. doi:http://dx.doi.org/10.1155/2015/608581.

43. Van der Kolk NM, King LA. Effects of Exercise on Mobility in People with Parkinson's Disease. Movement Disorders: Official Journal of Movement Disorder Society. 2013; 28(11): 1587-96.

44. Petzinger GM, Holschneider DP, Fisher B, McEwen S, Kintz N, Halliday M, et al. The Effects of Exercise on Dopamine Neurotransmission in Parkinson's Disease: Targeting Neuroplasticity to Modulate Basal Ganglia Circuitry. Brain Plasticity. 2015; 1(1): 29-39.

45. da Silva PG, Domingues DD, de Carvalho LA, Allodi S, Correa CL. Neurotrophic Factors in Parkinson's Disease are Regulated by Exercise: Evidence-based Practice. Journal of the Neurological Sciences. 2016; 363: 5-15.

46. Mello EM, Thais C, Renato SM, Thiago TG, Ercole da CR, Eduardo L, et al. Neuroscience of Exercise: From Neurobiology Mechanisms to Mental Health. Neuropsychobiology. 2013; 68(1): 1-14.

47. Mak MK, Wong-Yu IS, Shen X, Chung CL. LongTerm Effects of Exercise and Physical Therapy in People with Parkinson Disease. Natura Reviews Neurology. 2017; 13: 689-703.

48. Sandroff BM, Motl RW, Reed WR, Barbey AK, Benedict RHB, Deluca J. Integrative CNS Plasticity with Exercise in MS: The PRIMERS (Processing, Integration of Multisensory Exercise-Related Stimuli) Conceptual Framework. Neurorehabilitation and Neural Repair. 2018; 32(10): 1-16.

49. Liu W, Xue X, Xia J, Liu J, Qi Z. Swimming Exercise Reverses CUMS-Induced Changes in DepressionLike Behaviors and Hippocampal Plasticity-Related Proteins. Journal of Affective Disorders. 2018; 227: 126-35. 